Anuario Latinoamericano Ciencias Políticas

y Relaciones Internacionales

vol. 10,2020

pp. $169-186$

\section{The Choice for Intermediate Forces in Mexico. The Process of Creation of the Mexican Gendarmerie}

\author{
La elección de las fuerzas intermedias en México: \\ el proceso de la creación de la Gendarmería Mexicana
}

\author{
Marcos Pablo Moloeznik* \\ DEPARTMENT OF POLITICAL SCIENCE \\ UNIVERSITY OF GUADALAJARA, MEXICO \\ $\triangle$ mmoloeznik@yahoo.es \\ https://orcid.org/0000-0002-4078-9451
}

The Gendarmerie Division's function is to generate conditions of public safety, through operational deployment in situations where the presence of organized crime or a high crime rate threatens the life, liberty, integrity or heritage of citizens. (Federal Police, 2019)

\begin{abstract}
The process of militarization of public security in Mexico is presented under two modalities: the direct participation of the armed forces in the dimension of internal security and the commitment to the so-called intermediate forces or militarized police. Throughout this contribution, a review of the process of creating the Gendarmerie Division in the federal police is carried out, which responds to this second aspect.
\end{abstract}

KEYWORDS: intermediate forces, Gendarmerie, National Guard, Mexico.

\section{RESUMEN}

El proceso de militarización de la seguridad pública en México se presenta bajo dos modalidades: la participación directa de las fuerzas armadas en la dimensión de la seguridad interior y la apuesta por las denominadas fuerzas intermedias o policías

* Senior Professor-Researcher at the Department of Political Studies, CUCSH - University of Guadalajara (Mexico). National Researcher Level II, National Researchers System, CONACyT (Mexico). Visiting Professor at the International Institute of Humanitarian Law (Sanremo, Italy) for the last 7 years. He was granted the 2017 William J. Perry Award for Excellence in Security and Defense Education, William J. Perry Center for Hemispheric Defense Studies, National Defense University, Washington D.C. 
militarizadas. A lo largo de esta contribución se lleva a cabo una revisión del proceso de creación de la División de la Gendarmería en la policía federal que responde a esta segunda vertiente.

PALABRAS CLAVE: fuerzas intermedias, Gendarmería, Guardia Nacional, México.

\section{Introduction}

Throughout the historical evolution of Mexico, the successive governments - including those of political alternation - have used the armed forces as the primary response to public insecurity and violence. However, this process of militarization - the direct commitment of the military in the field of public security - is subjected to a continuous transformation. This change occurs with the creation of the National Gendarmerie in 2014 as a division of the federal police and, more recently, with the appearance of the National Guard (2019a) under the command of the army. Therefore, the choice is in favour of intermediate forces or militarized police, that privilege the repressive function of the State. This is the legacy of continental Europe and the antithesis of the civil police of Anglo-Saxon tradition.

The purpose of this contribution is to discuss in detail the nature of this coercive instrument created by the state to maintain the legitimate monopoly of force. For this, the process of creation of the National Gendarmerie Division in the federal police is carried out, based on the necessary analysis of the models of intermediate forces of the world.

\section{About intermediate forces: paramilitary forces and militarized police}

The International Committee of the Red Cross (ICRC) notes that:

In the majority of States the law enforcement bodies are civilian in origin and nature and are usually attached to the Ministry of the Interior or of Justice. Other States entrust law enforcement responsibility to military or paramilitary bodies, which operate under the responsibility of the Ministry of Defense. (De Rover, 2014, p. 133)

This last type of bodies is called security forces, also known as intermediate forces in the doctrine. Napoleon I, in a letter addressed to the King of Naples, described the French National Gendarmerie (from French "gens d'armes", men-at-arms) as a unique force in Europe that brings the most reliable information, "half civilian, half military" (Sénat, 2008). For this reason, the Gendarmerie had a double historical belonging to the Ministry of Interior and the Ministry of Defense (since January 2009 this institution is attached to 
the Ministry of Interior). It is considered as reserve for the armed forces, it has a military status, it is capable of combating in case of an armed conflict and its disciplinary regime is based in the code of military justice.

It is noteworthy than in the world there are two main models of intermediate forces, the National Guard of the United States of America and the National Gendarmerie of France. The "structure and organization [of these forces] will also depend on the political organization of the State [...] tend to have a strict hierarchical (military-type) set-up with as many functional levels as there are different ranks. They are mainly closed systems and most decisionmaking processes are of the 'top-down' variety” (De Rover, 2014. pp. 133, 327).

\section{United States National Guard}

The National Guard has its origins in the independence of the thirteen colonies based on the concept of "nation and people in arms" of the $18^{\text {th }}$ century. This concept consisted of a system of citizen militias, conformed by armed volunteers fighting for an independent nation, genesis of second-generation wars (Moloeznik, 2018c, pp. 49-50).

The National Guard reflects the federal model/pact because each state of the Union has this coercive instrument to its disposal and the governor is the supreme commander. Furthermore: "[...] at federal level, at regional/state level and sometimes even at municipal level. This often goes hand in hand with decentralized legislative powers and hence different laws governing the responsibilities and powers of the different structures at the federal, regional/ state and municipal level" (De Rover, 2014, p. 133).

The National Guard can be defined as the local armed force, composed by citizens, and trained by the respective state authorities, to defend and preserve the sovereignty of the country, peace, and internal order. In cases of emergency, this force is capable to solve critical situations, without mobilizing the Army, or bring an effective control until the military arrives.

It is intermediate force or militarized police that has a double nature, civilian and military at the same time, that justifies the constitutional power of the President of the United States to use it in cases of emergency, catastrophes or armed conflict, in his capacity of Commander in Chief of the Armed Forces. The National Guard is a coercive instrument capable to deal with emergencies and situations that can be considered as grey areas, between war and peace, that the ICRC names "other situations of violence" (OSV) (Moloeznik, 2018b, pp. 516-517). Consequently, it must be considered as a body used for reaction/repression, with personnel that is trained to face international armed conflicts (interstate or traditional) as well as non-international (intra-social) using the highest intensity of the force of a State, which legitimately monopolizes the use of force.

Summarizing, the United States National Guard is a decentralized model with a part time nature that comes from 1636, although recognized as part of the armed
The Choice for Intermediate Forces in Mexico. The Process of Creation of the Mexican Gendarmerie

Marcos Pablo Moloeznik 
forces of the emerging American state in 1775. It is composed of citizens that voluntarily join it and decide to use their free time in serving for this institution, while keeping their main civilian activity. Federalism constitutes a distinctive mark, because each state of the United Sates has its own National Guard to - in principle - respond to emergency situations, natural disasters, or public disorders.

\section{National Gendarmerie of France}

This corporation responds to the traditional conception of public order, foreseen in the Napoleonic Code of the $19^{\text {th }}$ century (Moloeznik, 2018c, p. 590). It is characterized by its military and centralized structure, extended throughout the entire territory. It focuses on the protection and extension of the political power of the governing persons or groups. Repressive and reactive on crime and at the service of the princeps or State, with the ultimate goal to maintain public order (Balbé, 1996, pp. 113-127).

The particularity of the gendarmerie is that it constitutes a pólice forcé with a military status. The gendarme is defined as the "soldier of law" because they are militaries in charge of a police mission, in the same manner as police officers. As established in Article 1 of the decree of 20 May 1903: "the gendarmerie is a force established to guarantee the public security and maintain the law and order". It is essentially a military force because of its organization, missions, and values. It is also known as the "fourth branch of the army" (Sénat, 2008).

This military dimension is very evident in terms of its modus operandi and characteristics (life in barracks and use of uniforms in particular), its ceremonialism and symbolism (for instance, its oath), and for the status and spirit of its personnel. The gendarmes are professional soldiers (career), subject to the military chief of staff (code of military justice) as defined by the law of 24 March 2005. According to it, it is forbidden for a gendarme, as for any other military personnel, to be associated with any political group or association. Furthermore, they are subjected to the duty of reserve, obligation of not diminishing the neutrality of the armies, prohibition to go on strike and freedom of association.

According to Vaultier: “The National Gendarmerie's missions are as follows: public order, restoring order, counterterrorist intervention, criminal investigation, prevention, assistance and rescue missions, surveillance of the territory and overseas police and military police [...] Overall, the activity of the gendarmerie breaks down into 50 percent civil defense, 40 percent criminal investigation, and 10 percent military missions" (2006, pp. 214-215).

Within this framework, the ICRC (2005b, p. 6) recognizes that: "Maintaining law and order is the responsibility of civil authorities. It is the task of the civil police and/or of paramilitary troops, such as gendarmeries, which are specially equipped, organized and trained for such missions". The politicaladministrative organization of France responds to the centralized nature of its State and therefore: "[...] the law enforcement body will usually be an equally 
centralized monolithic body with a vertical chain of command extending from the top central level to the lowest local level" (De Rover, 2014, p. 133).

In summary, the National Gendarmerie of France (1791) is a centralized and full-time model. It is a unique body that exercises its jurisdiction in all French territory, including the overseas possessions. Its members commit their entire life to this career that has two scales, one for the officials that will exercise the command and the other for the execution of the orders (gendarmes and non-commissioned officers).

The Armi di Carabinieri (1814) in Italy and the Civil Guard in Spain (1844) are created under the above-mentioned pattern:

Similarly to the French Gendarmerie, the Carabinieri are an integral part of the Italian armed forces - they constitute its fourth branch, after the army, the navy and the air force - and they have been involved in all the country's military conflicts. [...] Similarly to the French Gendarmerie, the Guardia Civil played a crucial role in the Spanish nation-building process in the nineteenth century and the consolidation of the central power over the more peripheral areas of the national territory. (Lutterbeck, 2004, pp. 48-49)

In the case of the Civil Guard, it is recognized that it "was born and developed at the service of the State, rather than at the service of civil society" (López Garrido, 2004, p. 12) and that "[it] has an organization and a military nature that is pyramidal, opposite of a network" (p. 16); proving that the Civil Guard played a fundamental role in the process of centralization of the Spanish State.

\begin{tabular}{|c|c|}
\hline National Guard & National Gendarmerie \\
\hline $\begin{array}{l}\text { Local Defense Units - armed local } \\
\text { personnel, domiciled at home, } \\
\text { typically without or with only partial } \\
\text { uniforms, and deployed in their own } \\
\text { area. Essentially part-time military } \\
\text { defense units used in connection with } \\
\text { internal armed insurrections. Called } \\
\text { militia in some developing countries. }\end{array}$ & $\begin{array}{l}\text { National Police Force - full-time "militarized" } \\
\text { police units, domiciled in barracks, equipped } \\
\text { with light military weapons and military } \\
\text { vehicles, and organized under the central } \\
\text { government. Includes frontier guards' units. } \\
\text { Often called gendarmerie. }\end{array}$ \\
\hline $\begin{array}{l}\text { The official birth date of the } \\
\text { Army National Guard as a reserve } \\
\text { component of the Army is December } \\
\text { 13, 1636. On this date, the } \\
\text { Massachusetts colonial legislature } \\
\text { directed that the colony's existing } \\
\text { militia companies be organized into } \\
\text { three regiments. }\end{array}$ & $\begin{array}{l}\text { The gendarmerie is the heiress of the } \\
\text { Maréchaussées, whose creation dates back to } \\
\text { the Hundred Years War (1337-1457) and whose } \\
\text { task was to control the excesses of the troops. }\end{array}$ \\
\hline
\end{tabular}

The Choice for Intermediate Forces in Mexico. The Process of Creation of the Mexican Gendarmerie

Marcos Pablo Moloeznik

\section{Table 1.}

Essential characteristics of the two models of intermediate forces 
The Militia Act of May 8, 1792, permitted militia units organized before the May 8, 1792, to retain their "customary privileges". This provision of the militia act was perpetuated by the Militia Act of 1903, the National Defense Act of 1916, and by subsequent law.

During peacetime, each state National Guard answers to leadership in the 50 states, three territories and the District of Columbia. During national emergencies, however, the President reserves the right to mobilize the National Guard, putting them in federal duty status. The Army National Guard's state mission is perhaps the most visible and well known. Nearly everyone has seen or heard of Guard units responding to battle fires or helping communities deal with floods, tornadoes, hurricanes, snowstorms, or other emergency situations. In times of civil unrest, the citizens of a state can rest assured that the Guard will be ready to respond, if needed. While federalized, the units answer to the Combatant Commander of the theatre in which they are operating and, ultimately, to the President. Even when not federalized, the Army National Guard has a federal obligation (or mission). That mission is to maintain professionally trained and equipped units, available for prompt mobilization for war, national emergency, or as otherwise needed. The Army National Guard is a partner with the Active Army and the Army Reserves in fulfilling the country's military needs.
On February 16, 1791, a law organized and created a new institution, successor of the old police: The National Gendarmerie.
The National Gendarmerie is placed under the authority of the Minister of the Interior, responsible for its organization, its management, its conditioning of employment and the necessary military infrastructure, without affecting the powers of the Minister of Defense for the execution of military missions of the National Gendarmerie and the judicial authority for the execution of its judicial missions. The Minister of Defense participates in the management of human resources of the National Gendarmerie in conditions defined by State's decree and exercises powers of discipline in the National Gendarmerie.

The gendarmerie can perform all of its missions in all situations likely to occur on the national territory (in times of peace as in times of war). It remains operational throughout the crisis arc. The gendarmerie is an armed force instituted to ensure public safety and security. It ensures the maintenance of order, the implementation of laws and judicial missions, and contributes to the intelligence activities. It contributes in all circumstances to the protection of populations. The gendarmerie participates in the defense of the Nation and protection of its highest interests.

The military organization of the National Gendarmerie is based on an integrated command, from an elementary unit (GM and GD) to general management (DGGN), allowing it to adopt a permanent operational stance, guaranteeing its reactivity and a strong capacity of mobilization. Faced with the suddenness of crises, it can adapt to different situations thanks to its ability to maneuver and change postures. To do this, it quickly regroups existing units, has training centers that can be deployed
Table 1. continued 


\begin{tabular}{|c|c|}
\hline & $\begin{array}{l}\text { anywhere and anytime, and implements } \\
\text { command and support resources. The National } \\
\text { Gendarmerie is thus a major player in crisis } \\
\text { management. }\end{array}$ \\
\hline $\begin{array}{l}\text { Typically, National Guard members } \\
\text { are required to attend one drill } \\
\text { weekend each month and one } \\
\text { annual training period (usually } 2 \\
\text { weeks in the summer) each year. } \\
\text { Weekend drills usually consist of one } \\
\text { Saturday and Sunday each month, } \\
\text { but occasionally include reporting for } \\
\text { duty on Friday night. } \\
\text { Initially, all non-prior service } \\
\text { personnel are required to attend } \\
\text { initial entry training (IET), also } \\
\text { known as Basic Training. After } \\
\text { Basic Training, soldiers go to their } \\
\text { Advanced Individual Training (AIT) } \\
\text { which teaches them the special skills } \\
\text { they will need for their job in the } \\
\text { Guard. These schools can usually be } \\
\text { scheduled to accommodate civilian } \\
\text { job or school constraints. } \\
\text { Training time is precious to Army } \\
\text { National Guard soldiers. }\end{array}$ & $\begin{array}{l}\text { Located in Rochefort-sur-Mer (Charente- } \\
\text { Maritime), the Command of Schools of the } \\
\text { National Gendarmerie (CEGN) directs and } \\
\text { coordinates all school activity and training } \\
\text { centers of the Institution: } \\
\text { - School of the officers of the National } \\
\text { Gendarmerie } \\
\text { Office (EOGN) in Melun; } \\
\text { - Gendarmerie schools in Châteaulin, } \\
\text { Chaumont, Dijon, Fontainebleau, Montluçon, } \\
\text { Rochefort and Tulle; } \\
\text { - } 14 \text { Training Centers. } \\
\text { School training for an officer: } 2 \text { years including } \\
\text { schooling and internships in unit. } \\
\text { School training for a gendarme: } 12 \text { months of } \\
\text { training including tuition and a complementary } \\
\text { training period in unit. } \\
\text { Specialist - NCOs of the Technical Support } \\
\text { Corps (CSTAGN) are recruited in } 6 \text { specialties: } \\
\text { personnel, administration and management, } \\
\text { logistics management and financial, real estate, } \\
\text { catering, armored auto-engines, armory and } \\
\text { pyrotechnics. }\end{array}$ \\
\hline $\begin{array}{l}\text { That is why the Guard uses many } \\
\text { unique training methods. From "real- } \\
\text { life" training exercises, like rotations } \\
\text { at the National Training Center in } \\
\text { Fort Irwin, California, to high-tech } \\
\text { simulation training and distributed } \\
\text { learning, the Army National Guard } \\
\text { employs innovative training methods } \\
\text { to give its members access to high } \\
\text { quality training. }\end{array}$ & $\begin{array}{l}\text { Officers of the Technical and Administrative } \\
\text { Corps (CTA) serve in } 3 \text { main areas: } \\
\text { administration, finance and logistics. } \\
\text { Voluntary - } 13 \text { weeks for police officers' judicial } \\
\text { assistants; } 13 \text { weeks for aspirants (AGIV); and } \\
6 \text { weeks for special jobs choice of position at } \\
\text { the time of application. At the end, possible } \\
\text { assignment on the whole territory according to } \\
\text { the proposed posts and ranking. } \\
\text { Reservist - has fulfilled the obligations of the } \\
\text { national military service and is less than } 40 \\
\text { years old on the first day of military preparation } \\
\text { for initiation or defense development } \\
\text { (PMIPDN). The preparation has a duration } \\
\text { of } 15 \text { days (preparation military police) or } \\
30 \text { days (military preparation superior of the } \\
\text { gendarmerie). }\end{array}$ \\
\hline
\end{tabular}

Source: Compiled by the author based on Zurcher and Harries-Jenkins (1978, pp. 11-12); National Guard (2019b); Gendarmerie Nationale (2019a and 2019b).
The Choice for Intermediate Forces in Mexico. The Process of Creation of the Mexican Gendarmerie

Marcos Pablo Moloeznik
Table 1.

continued 
The intermediate forces are a hard nucleus of the police in which the personnel have a "military state". These forces have their origins in the two biggest revolutionary movements of the $18^{\text {th }}$ century: the independence of the Thirteen Colonies in North America and the French Revolution, with the creation of the National Guard and the National Gendarmerie, respectively (Moloeznik \& Bravo Aguilar, forthcoming, pp. 16-17). These coercive instruments correspond to the first historical manifestations of the Rule of Law - also known as Liberal Rule of Law -, because the emphasis of the functions of the state apparatus relate to freedom and right to security (Díaz, 1985). The advantages of having this type of security forces is that in case of internal disturbances and tensions that surpass the capacities of civilian police, there is no need to use the armed forces (Moloeznik, 2018b, pp. 416-417).

Lutterbeck summarized the debate on the existence of these intermediate forces in the following way:

Analysis typically view the persistence of gendarmerie or paramilitary forces as somewhat of an anachronism or anomaly. Representing a continuation of military or quasi-military presence in domestic security, their existence is of course at odds with one of the basic principles - and indeed achievements - of the modern nation-state, at least in its liberal-democratic form: the separation between police and military. As militarized police forces, they are also often associated with authoritarian or repressive tendencies and are seen as a potential threat to civil liberties. In the following, however, it is argued that despite, or actually because of, their anomalous status, such intermediary forces have gained tremendously importance over recent years. Precisely because they combine the characteristics of police and military forces, they have come to play an increasingly salient role of the post-Cold War security agenda: in the field of border control [...] and that of peace support operations [...]. (2004, pp. 50-51)

Also, Easton and Moelker add to the academic debate on the militarisation of the police. They

[...] concentrate on two paradoxical trends. On the one hand, attention is being paid to the military character of police organisations, an issue which has been discussed since the advent of modern police forces [...] The core of this discussion is the impact of the military structure and culture on different aspects of our society. In the 19th and 20th centuries and up until now, military organisational principles are for example implemented in different kind of organisations such as religious groups, youth associations, hospitals and the police [...] On the other hand, the development of democracies raises questions about how to democratise/demilitarise police forces to meet all the 
requirements of a modern constitutional state. The concept of community policing is at the centre of this trend [...] Both trends are useful to conceptualise the impact of the blurring boundaries between the police and the armed forces upon the organisational and operational functioning of police forces all over the world. $(2010$, p. 2)

Currently, "the global trend of having civilian commands among the public security institutions is very clear: $75 \%$ of the countries have a complete or predominantly civilian command [...] In the last 20 years, countries such as Austria, Belgium, El Salvador, Guatemala, Luxemburg, Serbia and Ukraine, have pushed reforms to disappear the gendarmeries and have only civilian bodies" (Sánchez Valdés, 2019).

Regardless of the different positions, the intermediate forces are ad hoc coercive instruments to respond to the risks and threats to security in the PostWestphalian era (Arcudi, 2004) such as transnational organized crime and terrorism (through the border control and their presence in the areas where the state is weak), threats to the international peace and security - by taking part in peace-keeping missions - (Friesendorf, 2012), and other situations of violence in the domestic sphere, such as maintaining law and public order (International Committee of the Red Cross, 2015a, p. 7).

\section{The process of creation of the Mexican Gendarmerie}

The creation of the Mexican Gendarmerie constitutes an initiative of President Enrique Peña Nieto (2012-2018), who assumed it as commitment 76 in the Pact for Mexico signed on December 2, 2012: "the National Gendarmerie will be created as a body of territorial control that allows the exercise of the sovereignty of the Mexican State in all corners of the country, regardless of its remoteness, isolation or condition of vulnerability" (Government of Mexico/Ministry of the Interior, 2015c). Two weeks later, he instructed Miguel Ángel Osorio Chong, the Minister of Interior, to "initiate the works that would allow the creation of the Gendarmerie as soon as possible". This process started in March 2013, when the National Commissioner on Security ordered the Coordination of the Police Development System to take care of the planning and organization of the Gendarmerie - covering the areas of recruitment process, selection, evaluation and initial training of the future members of the Federal Police.

Among the most relevant aspects of the genesis of this public security body, the cooperation with the French National Gendarmerie can be highlighted. In December 2013, a delegation of the French Gendarmerie headed by Colonel Didier Chipoy visited Mexico with the objective to articulate collaboration mechanisms for the creation of its Mexican counterpart. In March 2014, a delegation of seven managers of the French Gendarmerie arrived in Mexico, headed by the Lieutenant-Colonel Raymond Laffont. They worked
The Choice for Intermediate Forces in Mexico.

The Process of Creation of the Mexican Gendarmerie

Marcos Pablo Moloeznik 
during four weeks in coordination with the team of the Police Development System (Sistema de Desarrollo Policial, SIDEPOL) on the design of the training programme of the managers of the Gendarmerie division and in various consultancies (Government of Mexico/Ministry of the Interior, 2015c).

In addition, in April 2014 the Declaration of Intention for the Creation of the Mexican National Gendarmerie is signed by the President of Mexico and his French counterpart. The said declaration implies technical exchange in terms of professionalisation and best practices for the implementation of the Mexican Gendarmerie. Thus, the French government offers to set up an adviser in Mexico, for the formation of the Gendarmerie Division of the Federal Police. The Lieutenant-Colonel of the French National Gendarmerie Raymond Laffond is appointed by the French government to hold this position.

Later, in August of the same year, the Technical Cooperation Convention between the Ministry of Interior of Mexico and the Minister of External Affairs and International Development of the French Republic is signed, defining the steps to the creation of a Gendarmerie Division in the Federal Police (Vizcaíno Zamora, 2017, pp. 46-47).

The Gendarmerie was officially born by virtue of the Decree of the Executive Power of the Federation in August 2014, that modifies and includes several dispositions to the Regulations of the Law of the Federal Police, converting the Gendarmerie in the seventh division of the Federal Police.

According to Article 17 of the Federal Police Regulation, the Division of Gendarmerie, has the following obligations:

I. Generate conditions of public security, through the operational deployment carried out in compliance with the defined attributions, in the following situations:

a) In the presence of organized crime or high crime rate, which threatens the life, freedom, integrity or property of citizens;

b) In the case of threat against people's sources of income, related to productive cycles; or,

c) In the event that, due to its importance, the General Commissioner determines that the presence of this Division is required to prevent the commission of crimes.

[...]

V. Propose and, where appropriate, execute operational tactical actions of deterrence, reaction, containment and reestablishment of public order in the facilities, events, communities, regions, areas and routes in which its members are deployed;

VI. Propose and, where appropriate, implement actions to provide security for the transit of people, goods and services in the facilities, events, communities, routes, regions or areas in which its members are deployed, in coordination with the competent bodies; 
IX. Participate in helping the population in action of civil protection nature in coordination with the competent authorities. (Presidency of Mexico, 2014)

For the Federal Police it was stated that:

The Division of Gendarmerie generates conditions of civilian security, protects people, and their sources of income in productive cycles, threatened by organized crime. Its presence reinforces the capacity of the Federal Police and will have coordinated actions with the people to prevent crimes in areas of risk. Its activity is directed at reducing the causes of crime, and the new model of operation responds to the needs of the country. (Government of Mexico/Ministry of the Interior, 2015a)

As put later by the government: "Its objective is to contain and dismantle those criminal organizations that undermine economic activity and restore public order and peace in accordance and respect of human rights" (Government of Mexico, 2019). Based on a new model of police operation, it is intended to contribute to the strengthening of the institutional capacities and territorial presence so that Mexicans can develop their activities in a calm environment. The new Division has the objective of protecting the security of people and the sources of income related to productive cycles that are at risk from threats of organized crime. (Government of Mexico/ Ministry of the Interior, 2015b). In particular, "[...] The powers given to the Gendarmerie to face the consequences that organized crime generates in the economic and productive cycles contribute [to generate the necessary conditions for the] citizens to carry out their activities regularly, protecting the sources of employment and economic development. It is a specific mission that no other police force has" (Vizcaíno Zamora, 2017, p. 109). It is a matter of "[...] guaranteeing the security of the population, of their goods in transit routes, of migrants, of agricultural, fishing and forestry production and of others that could be affected by crime in rural or marginalized areas; as well as collaborating with local authorities in the prevention of the perpetration of crimes, with the purpose of supporting economic development" (Belisario Domínguez Institute, 2014). Hence, "[...] the Division of Gendarmerie has the function of generating conditions of public security, through operational deployment in situations where the presence of organized crime or the high crime rates threaten the life, liberty, integrity or property of the population. Its deployment is also considered to face the threat against the sources of income of people in relation to the productive cycles, as well as in those events whose importance requires the institutional presence to prevent the commission of crimes" (Government of Mexico, 2019). To fulfil this purpose: "It is characterized for being mobile with removable barracks. It has wide capacity for operational deployment that allows it to move accord-
The Choice for Intermediate Forces in Mexico.

The Process of Creation of the Mexican Gendarmerie

Marcos Pablo Moloeznik 
ing to criminological and economic diagnoses, to provide security at strategic points. Its police operational mission in those areas of criminal risk will contribute to strengthening institutional capacities and territorial presence so that Mexicans can develop their activities with peace of mind" (Government of Mexico/Ministry of the Interior, 2015a).

In order to guarantee its missions, in August 2013, at the 20th Ordinary Session of the Police Development Council of the Federal Police, it is approved to open the admission process to the Gendarmerie Division, proceeding with the recruitment that eventually would manage to incorporate 5,000 troops (including 250 commanders selected from the Federal Police itself). These troops are subjected to a training process that integrates the contents of the military instrument:

The module of militarized training is an innovation in police training, because it provides the cadets with skills and abilities proper of the armed forces, with military discipline. The module represents 12\% (180 hours) of its training in San Miguel de los Jagüeyes with instructors from the Ministry of Defense, with subjects of order, development and physical conditioning, personal defense, weapons practices, shooting and tactical offensive reaction. (Government of Mexico/Ministry of the Interior, 2015a)

Its components are a group of cavalry and groups of special operations, reaction, social proximity, rural security, border security and tourist proximity (Government of Mexico/Ministry of the Interior, 2015b).

The person in charge of the design and implementation of the Gendarmerie Division of the Federal Police acknowledges that:

In the first months of 2013, when the Mexican Gendarmerie was under construction -construction that was preceded by political, legal and economic analysis - there were more questions than answers about the new institution. Political analysts, editorialists and academics formulated numerous questions through the media and social networks [...] In general terms, the gendarmerie construction process [...] concluded with the flag ceremony that led to the start of operations of the Gendarmerie Division of the Federal Police, on August 22, 2014, with its first 5,000 members. (Vizcaíno Zamora, 2017, pp. 3, 5)

In the view of Vizcaíno Zamora it was conceived as a coercive instrument that: "[...] performs both Public Security and Internal Security functions, which confirms its character as an intermediate institution between the Police and the Army. According to its legal framework is a new division - the seventh division - of the Federal Police. As such, its members have the same objectives as the rest of the members of the Federal Police [...]" (Vizcaíno Zamora, 2017, pp. 28-29). However, it is stands out from the rest of its peers because: 
[...] it specifically has the function of guaranteeing territorial control [...] it is composed by units with intermediate capacities between the police and the armies, their operational deployment can be similar to that of the armed forces. The gendarmeries can act at any geographical point in the territory of a nation and have the capacity to make temporary and itinerant deployments [...] The police, on the contrary, are deployed in specific and delimited geographical areas according to the distribution of their police stations and barracks, sometimes by blocks or sectors [...]. (Vizcaíno Zamora, 2017, p. 36)

For its creator: "The Gendarmerie Division of the Federal Police of Mexico lived a milestone moment when on July 14, 2015, it participated in the parade commemorating the national holiday of France. On the Avenue of Champs Elysees in Paris, the Mexican gendarmes marched in front of Presidents Françoise Hollande and Enrique Peña Nieto, after months of rigorous preparation for such an occasion, which included basic French courses and lectures on art, culture, French history and customs" (Vizcaíno Zamora, 2017, p. 48).

This event can be labeled as banal and frivol - in addition to unnecessary waste of resources. A master's thesis on police professionalization highlights on the Gendarmerie: "It was found that said police body appears as a campaign proposal without being based on a solid study or the feasibility of its implementation. Nevertheless, the Gendarmerie is created with structural problems that cannot be solved" (Gómez Rodríguez, 2016, p. 96).

However, the Federal Police, in general, and its Gendarmerie Division in particular, failed, since the statistics on crime of President Peña Nieto are truly catastrophic. Especially the first-degree murders - with rates higher than 20 homicides per one hundred thousand inhabitants - (National Institute of Statistics and Geography, 2017, 2018a, and 2018b; Executive Secretariat of the National Public Security System, 2017) and other crimes of high-impact, which are the ones that hurt the most people and contribute to generate a perception of insecurity and vulnerability among the population (Research Center for Development A.C., CIDAC, 2013).

Regarding the Mexican Gendarmerie, its architect Vizcaíno Zamora explains the reasons for its creation in the Mexico of the $21^{\text {st }}$ century:

First: to have a force that would ensure the territorial control of the Mexican state in those municipalities with a clear institutional weakness uncapable of facing the problems of public security that, having overflowed, constituted matters of Interior Security and consequently of the National Security agenda. Second: for the need to generate a security model that would contribute to the demilitarization of public security functions. Third: due to the consequences generated by organized crime in economic and productive cycles such as tourism or agriculture. Fourth: In the absence of credibility and confidence of the society in police institutions, it was necessary to build a police model that, due to the profile of its members and their professionali-
The Choice for Intermediate Forces in Mexico.

The Process of Creation of the Mexican Gendarmerie

Marcos Pablo Moloeznik 
zation, would acquire greater credibility and confidence than local and state police. Fifth: The Federal Police and the Armed Forces had intervened in the face of the absence or inability of local authorities to fight crime; so strengthening the Federal Police through a new Division with the characteristics of the Gendarmerie contributed to increasing the federation's capacities to support federal entities and municipalities. (2017, p. 71)

In particular, the deployment of the gendarmerie is considered in view of the threat against people's sources of income in relation to production cycles (Federal Police, 2019). However, the effective exercise of the national sovereignty, through territorial control and the permanent presence of the state - to the detriment of non-state actors - is a critical issue that falls within the scope of national security; and the permanent coverage of the Ministry of Defense responds to this - by having 12 Military Regions, that group 46 Military Zones, which at the same time are divided into Military Sectors and Subsectors - (Moloeznik, 2018a, p. 484).

In any case, it is worth asking why the deployment and coverage of the armed forces is insufficient, or why organized crime controls various municipalities and regions of the country - and affects economic and productive cycles such as tourism or agriculture - despite the presence of the uniformed gendarmes. The reader could question why, in order to demilitarize the function of public security, it is necessary to create a security force, or police with a militarized character. Ignoring that SEDENA and SEMAR (Ministry of Navy) are part of the National Public Security Council, the highest instance of coordination and definition of public policies in the matter. In short, there are military and sailors actively participating in the decision-making process related to public security (Moloeznik, 2018a, p. 503).

Also, modifying the negative social perception of police institutions is a complex long-term process that can only be achieved through the transformation, modernization and professionalization of enlisted personnel and within the framework of civil police model based on the proximity. It translates into limiting the interventions of the central government and strengthening the capacities of the state police within the framework of federalism and, selectively, of the recoverable municipal ones. There is a perverse incentive in allocating resources to a coercive apparatus of the central government, instead of betting on the state and municipal police, relying on the interference of the central power in matters of public security. This also adds to the burden of allocating resources to the Gendarmerie in detriment of the state and municipal police forces.

\section{Conclusions}

In contrast to the Mexican Gendarmery, the United States National Guard and the French National Gendarmerie are maintained and consolidat- 
ed throughout the years, beyond the government in turn. Furthermore, these institutions generate intangible elements such as traditions (including myths), symbols, strategic thinking and doctrine, mysticism of service, sense of belonging or principle of identity of its members, leadership, trust, loyalty, integrity, prestige, and esprit de corps; with positive effects that transcend any political agendas.

Additionally, they professionally retain and develop enrolled personnel and the process of formation and training of the human critical mass is continuous and constant. It is reflected in the organizational results and in the high social recognition they enjoy. Both intermediate forces are born in the heat of the bourgeois revolutions of the late eighteenth century, adapt to changing environmental circumstances, and coexist with civil police; given that 75 percent of nation-states opt for the civil police model and civilian controls (Sánchez Valdés, 2019).

On the contrary, the Mexican governments of the last decade are committed to a police model based on the militarization, characterized by its centralization and hierarchy composed of military commanders, while the global trend is towards the demilitarization of police institutions, encouraging decentralization processes and mission-type orders. In other words, since Mexico is a federal country, instead of betting on police decentralization, it insists on the consolidation of a highly centralized model for public security. Paradoxically, the process of militarization of the public security apparatus takes place under democratic governments of political alternation (Moloeznik, 2018a, p. 485; Moloeznik \& Medina Nuñez, 2019). In conclusion, opting for intermediate forces with the creation of a national gendarmerie within the federal police once again demonstrates the desire of the central government to bet on the model of militarized police.

\section{References}

Balbé, M. (1996). Modelos policiales comparados. VII Seminario "Duque de Ahumada", Seguridad y Estado Autonómico. Madrid: Ministerio del Interior.

Belisario Domínguez Institute (2014). La Gendarmería Nacional en México. Mirada Legislativa, no. 60, México: Dirección General del Análisis Legislativo, Senado de la Republica. Retrieved from http://bibliodigitalibd.senado.gob.mx/bitstream/handle/1234 56789/2002/ML60.pdf? sequence $=1$ \&isAllowed $=y$

De Rover, C. (2014). To Serve and to Protect. Human Rights and Humanitarian Law for Police and Security Forces. Second edition revised and updated by Anja Bienert. Geneva: ICRC. Retrieved from https://shop.icrc.org/catalogsearch/result/?q=Serve+and+protect

Díaz, E. (1985). Estado de Derecho y sociedad democrática. Madrid: Taurus.

Easton. M. \& Moelker, R. (2010). Police and Military: Two Worlds Apart? Current Challenges in the Process of Constabularisation of the Armed Forces and Militarisation of the Civilian Police. In M. Easton et al. (eds.), Blurring of Military and Police Roles.
The Choice for Intermediate Forces in Mexico. The Process of Creation of the Mexican Gendarmerie

Marcos Pablo Moloeznik 
The Hague: Eleven International Publishing, pp. 1-17. Retrieved from https://www. researchgate.net/publication/301198652_'Police_and_Military_Two_Worlds_Apart_in_ Easton_M_M_den_Boer_J_Janssens_R_Moelker_T_van_den_Beken_Eds _Blurring_of_ Military_and_Police_Roles

Executive Secretariat of the National Public Security System (2017). Tasas por cada $100 \mathrm{mil}$ habitantes 1997-2017. México: SESNSP. Retrieved from http://secretariadoejecutivo.gob. $\mathrm{mx} /$ docs/pdfs/tasas por cada $100 \mathrm{mil}$ habitantes/Tasas012018.pdf

Federal Police (2019). División de Gendarmería de la Policía Federal. Retrieved from https://www.gob.mx/policiafederal/articulos/division-de-gendarmeria-de-la-policiafederal?idiom $=$ es

Friesendorf, C. (2012). International Intervention and the Use of Force: Military and Police Roles. The Geneva Centre for the Democratic Control of Armed Forces (DCAF). Retrieved from https://www.peacepalacelibrary.nl/ebooks/files/383260469.pdf

Gendarmerie Nationale (2019a). La gendarmerie de sa naissance à aujourd'hui. Paris: Ministère de l'intérieur. Retrieved from https://www.gendarmerie.interieur.gouv.fr/Notreinstitution/Notre-histoire/La-gendarmerie-de-sa-naissance-a-aujourd-hui

Gendarmerie Nationale (2019b). Mémogend 2019. Retrieved from https://www. gendarmerie.interieur.gouv.fr/Notre-communication2/Publications-Documentations/ MemoGend/Memogend-2019

Gómez Rodríguez, J. (2016). Profesionalización Policial en la Administración Pública Federal, 2012 - 2014. MSc tesis. Texcoco: Universidad Autónoma del Estado de México. Retrieved from http://ri.uaemex.mx/bitstream/handle/20.500.11799/65206/TESIS\%20 definitiva-janeth.pdf? sequence $=1$ \&isAllowed $=y$

Government of Mexico (2019). División de Gendarmería de la Policía Federal. Blog Policía Federal, 27 March. Retrieved from https://www.gob.mx/policiafederal/articulos/divisionde-gendarmeria-de-la-policia-federal?idiom $=$ es

Government of Mexico/Ministry of the Interior (2015a). Policía Federal. División de Gendarmería. Comisionado Nacional de Seguridad, 10 September. Retrieved from http:// www.cns.gob.mx/portalWebApp/wlp.c?_c=1f404

Government of Mexico/Ministry of the Interior (2015b). Diez puntos para comprender qué es la División de Gendarmería. Comisionado Nacional de Seguridad, 10 September. Retrieved from http://www.cns.gob.mx/portalWebApp/wlp.c?_c=1f406

Government of Mexico/Ministry of the Interior (2015c). Conformación de la División Gendarmería/Cronología. Comisionado Nacional de Seguridad, 10 September. Retrieved from http://www.cns.gob.mx/portalWebApp/wlp.c;jsessionid=2dn1dGyWm1x3wMWTyp mGLnZKFZ0NhpnGCT4LGwbn2TJYvMCz4wJ4!-329272371?_c=1f405

International Committee of the Red Cross (2005a). To Serve and to Protect: Guide for Police Conduct and Behaviour. Geneva: ICRC. Retrieved from https://shop.icrc.org/toserve-and-to-protect-guide-for-police-conduct-and-behaviour.html

International Committee of the Red Cross (2005b). Violence and the Use of Force. Geneva: ICRC. Retrieved from https://shop.icrc.org/violence-et-usage-de-la-force-871.html

López Garrido, D. (2004). La Guardia Civil y los Orígenes del Estado Centralista. Madrid: Alianza Editorial.

Lutterbeck, D. (2004). Between Police and Military. The New Security Agenda and the Rise of Gendarmeries, Cooperation and Conflict. Journal of the Nordic Inter- 
national Studies Association, no. 39(1), pp. 45-68. https://journals.sagepub.com/ doi/10.1177/0010836704040832

Moloeznik, M.P. (2018a). Tratado sobre pensamiento estratégico-militar. Enseñanzas para el Sistema de Defensa de México. México: Colectivo de Análisis de la Seguridad en Democracia, A.C. (CASEDE). Retrieved from https://www.casede.org/index.php/ biblioteca-casede-2-0/defensa-y-fuerzas-armadas/fuerzas-armadas-mexicanas/410tratado-sobre-pensamiento-estrategico-militar

Moloeznik, M.P. (2018b). Internal Disturbances and Tensions. In D. Djukić \& N. Pons (eds.), The Companion to International Humanitarian Law. Leiden and Boston: Brill and Nijhoff Publishers, pp. 416-418.

Moloeznik, M.P. (2018c). Public Order and Safety. In D. Djukić \& N. Pons (eds.), The Companion to International Humanitarian Law. Leiden and Boston: Brill and Nijhoff Publishers, pp. 590-591.

Moloeznik, M.P. \& Medina Nuñez, I. (eds.). (2019). Contextualizaciones Latinoamericanas. Proceso de militarización de la seguridad pública en América Latina. Guadalajara: Universidad de Guadalajara.

Moloeznik, M.P. \& Bravo Aguilar, N.T. (eds.). (forthcoming). Libro blanco de la guardia nacional (Abordaje y análisis de expertos y actores nacionales e internacionales). Paper presented at the LXIV Legislature of the Chamber of Deputies, 8 and 9 January 2019, Mexico City.

National Institute of Statistics and Geography (2017). Base de datos de defunciones generales. México: INEGI. Retrieved from http://www.beta.inegi.org.mx/proyectos/ registros/vitales/mortalidad/

National Institute of Statistics and Geography (2018a). Datos preliminares revelan que en 2017 se registraron 31 mil 174 homicidios. Comunicado de prensa no. 310/18. México: INEGI. Retrieved from https://www.inegi.org.mx/contenidos/saladeprensa/ boletines/2018/EstSegPub/homicidios2017_07.pdf

National Institute of Statistics and Geography (2018b). Mortalidad: Defunciones generales. Registros Administrativos. México: INEGI. Retrieved from https://www.inegi.org.mx/ programas/mortalidad/default.html\#Microdatos

National Guard (2019a). How we began. Retrieved from https://www.nationalguard.mil/ About-the-Guard/How-We-Began/

National Guard (2019b). Army National Guard. Federal Mission \& State Mission. Retrieved from https://www.nationalguard.mil/About-the-Guard/Army-National-Guard/

Presidency of Mexico (2014). Decreto por el que se reforman y adicionan diversas disposiciones del Reglamento de la Ley de la Policía Federal. DOF: 22/08/2014. México: Diario Oficial de la Federación. Retrieved from https://www.dof.gob.mx/nota_detalle.php? codigo $=5357363 \&$ fecha $=22 / 08 / 2014$

Sánchez Valdés, V. M. (2019). Seguridad pública en el mundo: ¿quién está al mando?. Nexos, 7 January. Retrieved from https://seguridad.nexos.com.mx/?p=1184

Sénat (2008). Quel avenir pour la gendarmerie?. Rapport d’information n²7 (2007-2008) fait au nom de la commission des affaires étrangères. Paris, 10 avril 2008. Retrieved from https://www.senat.fr/rap/r07-271/r07-271_mono.html\#toc0

Vaultier, D. (2006). The Military's Role in Homeland Security in France. In J. L. Clarke (ed.), Armies in Homeland Security. American and European Perspectives. Washington, D.C.: National Defense University, pp. 203-230. Retrieved from https://www.hsdl. org/?view\&did $=481961$
The Choice for Intermediate Forces in Mexico. The Process of Creation of the Mexican Gendarmerie

Marcos Pablo Moloeznik 
Artículos y ensayos

Vizcaíno Zamora, A. (2017). La Gendarmería Mexicana. MSc thesis, Universidad Panamericana, México. Retrieved from http://biblio.upmx.mx/tesis/191728.pdf

Zurcher, L. A. \& Harries-Jenkins, G. (1978.) Introduction. In L. A. Zurcher \& G. HarriesJenkins (eds.), Supplementary Military Forces. Reserves, Militias, Auxiliaries. Beverly Hills and London: Sage Publications, pp. 17-34. 